\title{
Experimental study of unsafe drinking water treatment with Moringa oleifera oilcake by coagulation flocculation and filtration
}

\author{
Kaboré Aminata1*, Savadogo Boubacar ${ }^{2}$, Zongo Inoussa ${ }^{3}$, Sawadogo Jacques ${ }^{1}$, Savadogo W. Paul', \\ Nombré Ivette Nina 4 \\ 1'Institut de l'Environnement et de Recherches Agricoles, 04 BP 8645, Burkina Faso \\ 2Institut de Recherché en Sciences de la Santé, 03 BP 7192, Ouagadougou, Burkina Faso \\ 3Institut de Recherche en Sciences Appliquées et Technologies, 03 BP 7047, Burkina Faso \\ ${ }^{4}$ ONG Eau et Assainissement pour l'Afrique, 03 BP 7112 Ouagadougou 03 Burkina Faso, \\ * Corresponding author: kab.amina@yahoo.fr Tel: +22670385699
}

Original submitted in on $5^{\text {th }}$ November 2019. Published online at www.m.elewa.org/journals/ on $31^{\text {st }}$ January 2020 https://doi.org/10.35759/JABs.v146.1

\begin{abstract}
Objectives: This study aimed to develop a treatment process, which improves the organoleptic and microbiological qualities of drinking water treated by coagulation flocculation with Moringa oleifera seeds. Methodology and Results: Moringa oleifera oilcake was used for coagulation flocculation. To treat water with turbidity 51.2 to $1142.9 \mathrm{NTU}, 600 \mathrm{mg} / \mathrm{L}$ to $2 \mathrm{~g} / \mathrm{L}$ of coagulant were used. Sand filtration was carried out to remove the residual organic matter and microbes in water after the coagulation flocculation. With this method, 93.43 to $99.87 \%$ of turbidity was removed versus $37.38 \%$ to $93.43 \%$ for water treated only by coagulation flocculation. After coagulation flocculation 61.9 to $85.18 \%$ of faecal coliforms, 61.18 to $100 \%$ of E. coli and $69.88100 \%$ of faecal streptococci were removed versus $100 \%$ of all faecal bacteria after filtration.

Conclusion and application of findings: The sand filtration combined to coagulation flocculation with Moringa oleifera oilcake removed the turbidity and faecal bacteria in water and provide drinking water conform to WHO standards. Furthermore, this method provided water except for bad taste and smell. In view of these results, a household treatment process adapted to the socio-economic conditions of rural populations should be formulated to popularise this technology of drinking water treatment. Moringa seeds, sand and shea charcoal are available and easy to get to rural population. The process is also fast and easy to implement in the households.
\end{abstract}

Keywords: Drinking water, Moringa oleifera, treatment, physical chemistry, microbiology.

\section{INTRODUCTION}

The consumption of unsafe drinking water poses health risks. In low and middle-income countries, a large part of population particularly those living in rural areas has a limited access to safe drinking water. According to World Health Organization (WHO), 2\% of world population still consume unsafe water and among them 94\% live in rural areas (WHO/UNICEF, 2018). In Burkina Faso, authorities to increase the access to safe drinking water through supply infrastructures (PN-EAP, 2018) have done many investments. Despite these efforts, around $27 \%$ of population do not access to 
improved infrastructures of supply drinking water with a disparity between town and villages (CABRI, 2017, PN-EAP, 2018). Therefore, the rate of access is $95.3 \%$ in urban areas versus $69.5 \%$ in rural areas with 196 villages, which do not have drillings (INSD, 2015; CABRI, 2017; PN-AEP, 2018). Furthermore, $24 \%$ of drillings are not function permanently. All these factors are the causes of the consumption of unsafe drinking water. In fact, $3 \%$ of rural people still consume surface water and $30 \%$ well water contaminated by faecal microorganisms (Savadogo et al., 2013; CABRI, 2017). Diseases associated to unsafe drinking water cause many deaths worldwide and affect consequently on the economy of the country (Van Minh et al., 2011; Traoré \& Sié, 2017). In Burkina Faso, more than 4,000 children death

\section{MATERIALS AND METHODS}

Moringa oleifera oilcake: The treatment of unsafe drinking water with Moringa oleifera seeds consists in coagulation flocculation, which removes turbidity and microorganisms. This process is more effective with oilcake (Kaboré et al., 2013b). Furthermore, oilcake induces less organic matter and lipids, which damage the organoleptic quality of treated water. For this study, Moringa oleifera seeds were sorted and pressed with a press machine ZX10 to extract the oil. This method has a good oil yield (30\%) and conserves active proteins involved in flocculation coagulation of unsafe water (Kaboré et al., 2013b). After press, the oilcake were every year because of the consumption of unsafe water (WHO, 2014). In view of this situation, appropriate treatment of unsafe water in household with natural substances could be an efficient alternative to supply safe drinking water in rural area. Studies showed the effectiveness of Moringa oleifera seeds and oilcake to clarify surface and well waters by coagulation flocculation (Vikashni et al., 2012; Kaboré et al., 2013a, 2013b). However, the residual organic matter from Moringa oleifera seeds damages the organoleptic quality of treated water (Kaboré et al., 2013a, 2013b). Then, for waters with low turbidity, a poor elimination of faecal bacteria and a long settling time was observed (Kaboré et al., 2013b; 2015). In view of these deficiencies, a sand filtration was done to get safe drinking water according to WHO standards.

dried and crushed to obtain a fine powder using the procedure described by Folkard et al., (2002).

The filtration device: $A$ sand filter was designed with two plastic buckets. In the first bucket (40 litres), $30 \mathrm{~cm}$ of fine sand $(0.25 \mathrm{~mm})$ and $5 \mathrm{~cm}$ of shea charcoal (3.5 $\mathrm{mm}$ ) were arranged. These materials were washed and sterilized at $150^{\circ} \mathrm{C}$ in the oven for one (1) hour (Sawadogo, 2019). In the bottom of the first bucket was used as a filter, hundreds of small gaps around $2 \mathrm{~mm}$ in diameter were made to filter water and collect it in the second bucket of 15 litres. On the second bucket, a tap was fixed to collect the water for drinking. Figure 1 shows the filtration device.

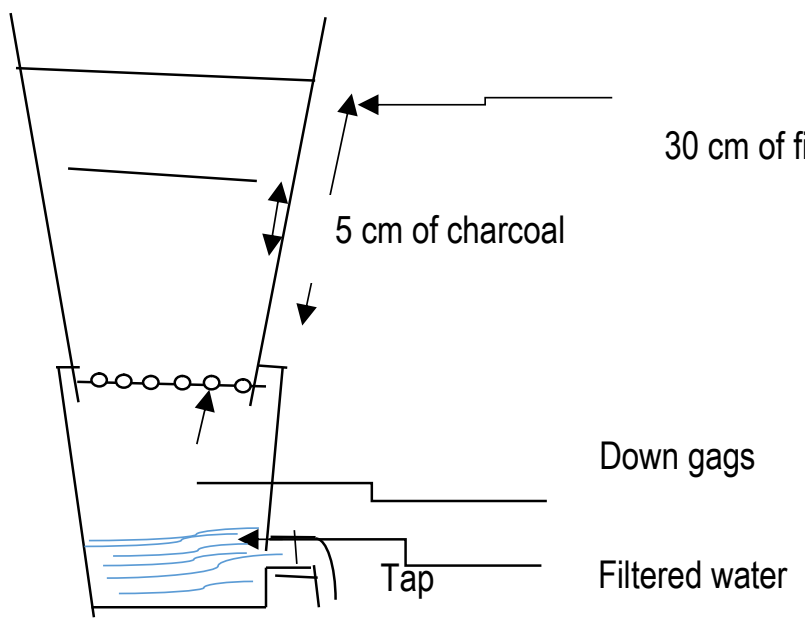

Figure 1: Water filtration device 
Jar tests and water treatment: To carry out the jar tests, $20 \mathrm{~g}$ of oilcake powder were dissolved in one (1) litre of distilled water. The mixture was stirred for one (1) hour to extract the active proteins (Kaboré et al., 2013a, 2013b). Increasing volumes of this solution (coagulant) were tested to clarify $500 \mathrm{~mL}$ of water with different turbidity. These jar tests were necessary to define the optimal concentration of coagulant and the settling time required for water clarification. After the jar tests, 10 litres of unsafe water were treated with appropriate volumes of coagulant. For these quantities of water, the stirring were carried out with a spatula in two (2) times: a quick mixing for one (1) minute for a homogeneous distribution of coagulant and a slow mixing for three (3) to five (5) minutes to stimulate the flocks. At the end of this step, water was left to decant for 15 minutes before sand filtration and 30 minutes for those treated only by coagulation-flocculation (Kaboré et al., 2013b). In this study seven (7) water sample were used.

Water analysis: To evaluate the effectiveness of these different treatments, organoleptic, physicochemical and microbiological analysis was carried out on raw, decanted and filtered water.

Organoleptic and physicochemical analysis: Organoleptic parameters were taste and smell. These parameters were assessed according to French Standard EN 1622 (Rodier et al., 2009). Turbidity, pH,

\section{RESULTS AND DISCUSSION}

Raw water quality and optimal treatment conditions: The concentration of coagulant, the settling time, and the effectiveness of the coagulation flocculation depends on the initial characteristics of raw water (Kaboré et al., 2013a, 2013b). To optimize the conductivity and nitrates were analysed in raw water and after coagulation flocculation and filtration. Turbidity were measured with turbidimeter, $\mathrm{pH}$ and conductivity at $25^{\circ} \mathrm{C}$, according to ISO 7027 Standard and NF T 90008 respectively (Rodier et al., 2009). Nitrates were analysed according to the molecular absorption method ISO 7890-3.

Microbiological analysis: Three (3) bacterial indicators of faecal contamination namely Escherichia coli, faecal coliforms, faecal streptococcus were analysed by the method of membrane filtration technique (NF ISO 8199, 2018). Bacterial cells were concentrated on a $0.2 \mu \mathrm{m}$ millipore membrane filter followed by culture on the chromogenic Rapid E. Coli 2 Agar (BIO RAD) medium that contains 2 substrates specific to the $\beta$-D-Glucuronidase (Gluc) and $\beta$-DGalactosidase (Gal) enzymes respectively. Incubation was performed at $44.5^{\circ} \mathrm{C}$ for $24 \mathrm{~h}$. Colonies of $E$. coli (Gal+/Gluc+) appear violet to pink while other coliforms colonies stain blue. On the Bile Esculine Azide medium, Gram-positive cells able to reduce Esculine as faecal streptococcus stain black after $24 \mathrm{~h}$ incubation period at $37^{\circ} \mathrm{C}$, while Gram negative and other Gram positive cells are inhibited by sodium Azide.

Statistical analysis: Data were analysed with the statistical analysis software R. The graphs were realized with excel.

treatments, the physicochemical and microbiological parameters of raw water, the optimal concentration of coagulant and the settling time were determined. Table 1 presents the physicochemical and microbiological parameters of raw water.

Table 1: physicochemical and microbiological parameters of raw water

\begin{tabular}{|l|lllllll|}
\hline Sample & $\mathbf{S}_{1}$ & $\mathbf{S}_{2}$ & $\mathbf{S}_{3}$ & $\mathbf{S}_{4}$ & $\mathbf{S}_{5}$ & $\mathbf{S}_{6}$ & $\mathbf{S}_{7}$ \\
\hline Turbidity $(\mathrm{NTU})$ & 1142,9 & 446,42 & 287,92 & 377,08 & 242,51 & 85,73 & 51,2 \\
\hline $\mathrm{pH}$ & 7,92 & 7,64 & 7,82 & 7,74 & 7,58 & 7,65 & 7,62 \\
\hline Conductivity $(\mu \mathrm{S} / \mathrm{cm})$ & 140,3 & 138,3 & 137 & 137,2 & 130,4 & 130,5 & 127,5 \\
\hline Nitrates $(\mathrm{mg} / \mathrm{L})$ & 31,33 & 10,24 & 7,12 & 22,9 & 20,8 & 9,02 & 27,3 \\
\hline Faecal coliforms (UFC/100 ml) & 10240 & 6220 & 2630 & 810 & 540 & 270 & 110 \\
\hline E. coli (UFC/100ml) & 8120 & 3710 & 240 & 120 & 80 & 0 & 0 \\
\hline Faecal streptococci (UFC/100 ml) & 7470 & 4200 & 970 & 530 & 180 & 70 & 10 \\
\hline Concentration of coagulant $(\mathrm{g} / \mathrm{L})$ & 2 & 1 & 0.8 & 0.8 & 0.6 & 0.6 & 0.6 \\
\hline
\end{tabular}

These results show the turbidity and microbiological parameters (faecal coliforms, E. coli and faecal streptococci) of raw water are not conform to drinking water standards (WHO, 2011). Considering rural populations consume these waters, it is necessary to apply an appropriate treatment. To clarify water with 
turbidity 1142.9 and $446.42 \mathrm{NTU}, 2 \mathrm{~g} / \mathrm{L}$ and $1 \mathrm{~g} / \mathrm{L}$ of oilcake coagulant were used respectively. For those with 287.92 and $377.08 \mathrm{NTU}, 800 \mathrm{mg} / \mathrm{L}$ was used for coagulation flocculation. $600 \mathrm{mg} / \mathrm{L}$ of coagulant was used for water with 242.51, 85.73 and 51.2 NTU (Table 1). The optimum settling time was 15 min before sand filtration and $30 \mathrm{~min}$ if water was treated only by coagulation flocculation. For water with low turbidity or containing clays particles, the efficiency of coagulation flocculation decreased and the treatment requires high concentrations of coagulant and a long settling time (Kaboré et al., 2013a; 2013b).

Effects of treatments on the physicochemical parameters of waters: Figures $2 a, 2 b$, and $2 c, 2 d$ show the effects of coagulation flocculation $\left(T_{1}\right)$ and coagulation flocculation combined with filtration $\left(T_{2}\right)$ on turbidity, nitrates, $\mathrm{pH}$ and conductivity of waters.

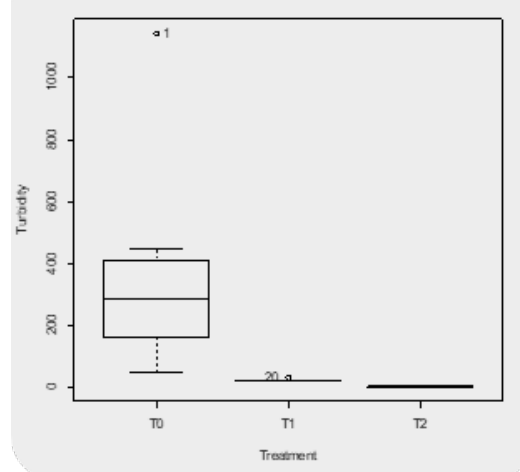

(a)

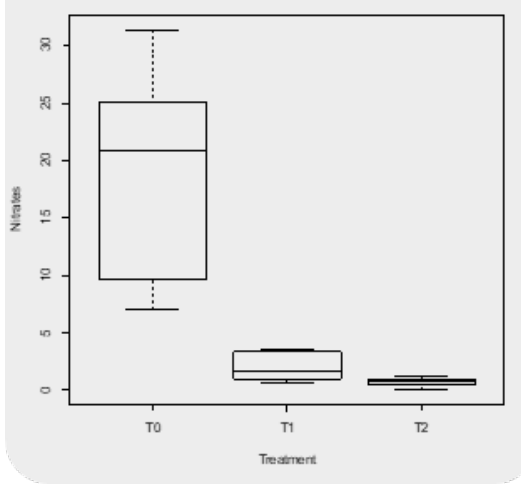

(b)

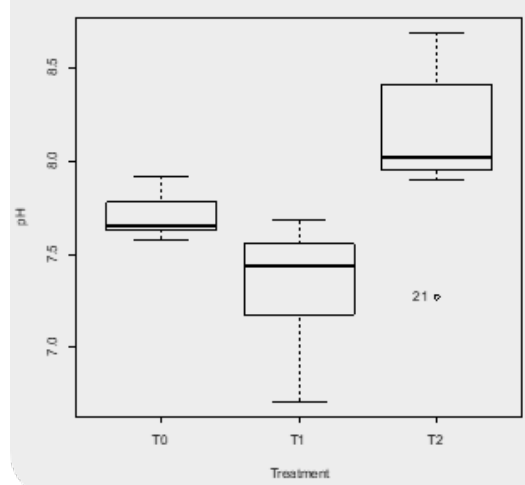

(c)

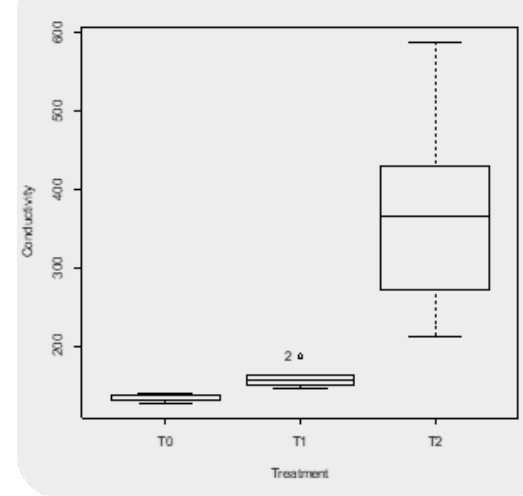

(d)

Figure 2: Effects of treatments on turbidity (a), nitrates (b), pH and conductivity (d) of waters

For all water, coagulation flocculation only or associated with sand filtration removed significantly the turbidity $(p<0.00598)$ and nitrates $\left(p<1.74 e^{-05}\right)$ (Figures $2 a, 2 b)$. In contrast, sand filtration increased significantly $\mathrm{pH}(\mathrm{p}<0.00203)$ and conductivity $(\mathrm{p}<2.63 \mathrm{e}-$ 05) (Figures 2c, 2d).
Efficiency of sand filtration on physicochemical quality of water after coagulation flocculation: Figures 3 and 4 show the physicochemical quality of raw water treated by coagulation flocculation $\left(T_{1}\right)$ and filtration $\left(T_{2}\right)$. 


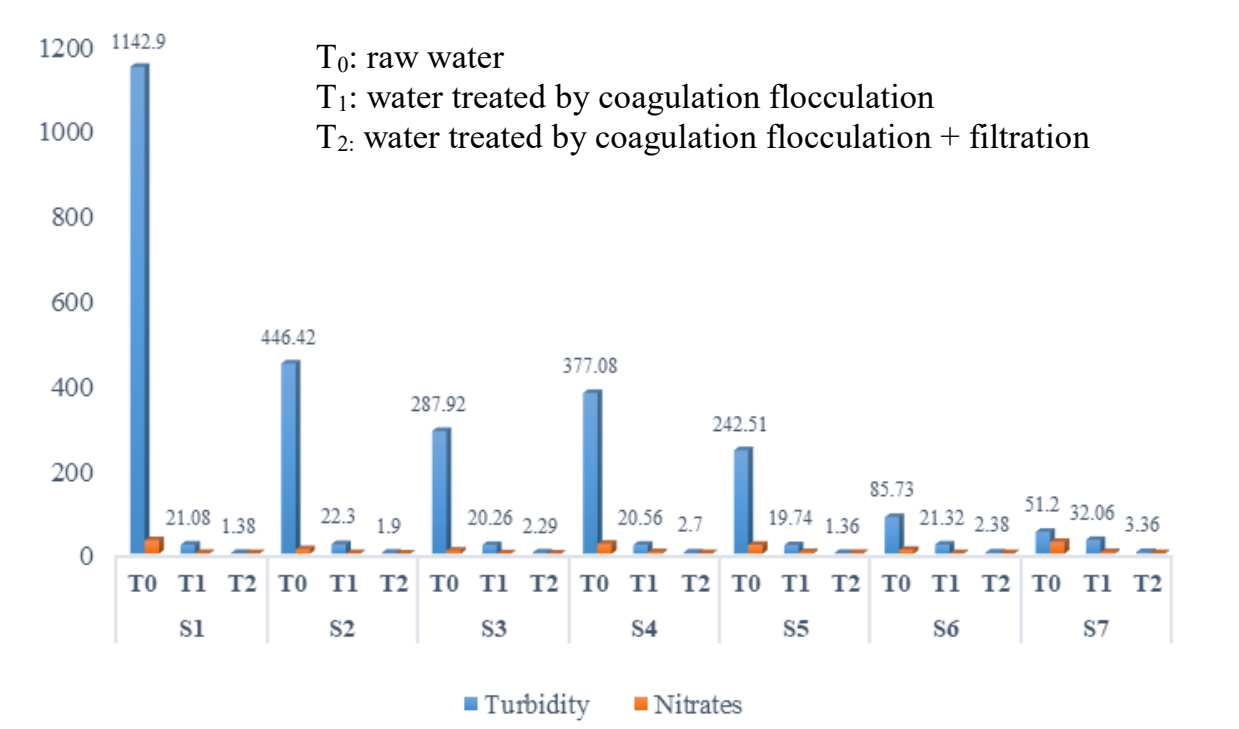

Figure 3: Turbidity and nitrates in raw water, after coagulation flocculation $\left(T_{1}\right)$ and filtration $\left(T_{2}\right)$

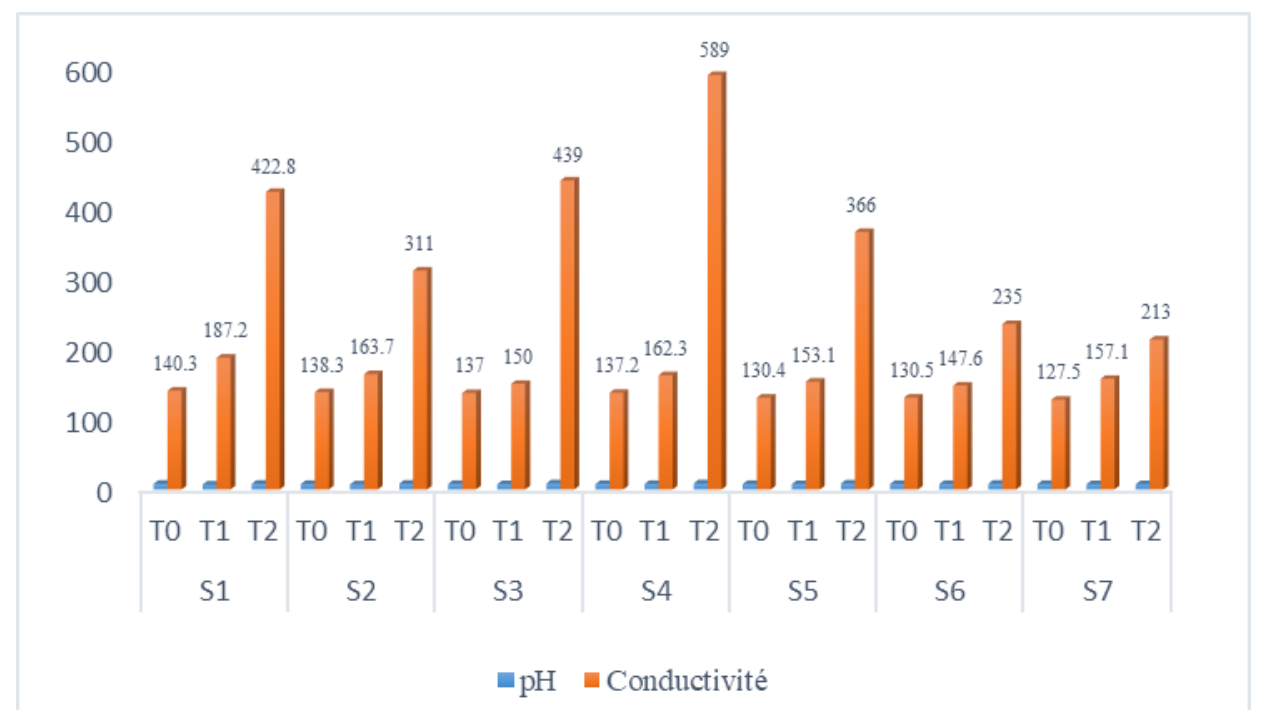

Figure 4: $\mathrm{pH}$ and conductivity in raw water after coagulation flocculation $\left(\mathrm{T}_{1}\right)$ and filtration $\left(\mathrm{T}_{2}\right)$

Depending on water type, $37.38 \%$ to $93.43 \%$ of the turbidity and 83.65 to $94.66 \%$ of the nitrates were removed with coagulation flocculation only (figure3). With this method, no water presented an acceptable turbidity according to WHO standards after $30 \mathrm{~min}$. However, combining sand filtration, the turbidity of all water was conforming to standards after $15 \mathrm{~min}$. Concerning nitrates; coagulation flocculation was efficient for all water. The conductivity of all water were increased with treatment without exceed standards (figure4). Its effect on pH was no significant (Figure 2c). It appears that to treat water with low or very high turbidity or whose contain fine particles like clays, the coagulation flocculation require a high concentration of oilcake coagulant a long settling time. The use of high concentrations of coagulant damages the organoleptic quality of treated water because of residual organic matter from oilcake (Kaboré et al., 2013a, 2013b). Thus, sand filtration is necessary after coagulation flocculation to get safe drinking water quickly. Combining flocculation coagulation with sand filtration $\left(T_{2}\right)$, the results of turbidity and nitrates were better than those obtained with coagulation flocculation only. In fact, for this treatment, 93.43 to $99.87 \%$ of turbidity and 90.24 to $98.92 \%$ of nitrates were removed depending on water type (figure3). The analysis of the organoleptic quality of water after filtration showed neither unpleasant taste nor disagreeable smell. Furthermore, 
the combination of filtration reduces the processing time from 30 min minimum to $15 \mathrm{~min}$. That is an advantage for a domestic implementation. The significant increase of conductivity and $\mathrm{pH}$ in filtered water is probably causes by filtration materials (figure4). Figure 3 shows raw water (sample 2) and after flocculation coagulation $\left(T_{1}\right)$ and filtration $\left(T_{2}\right)$.

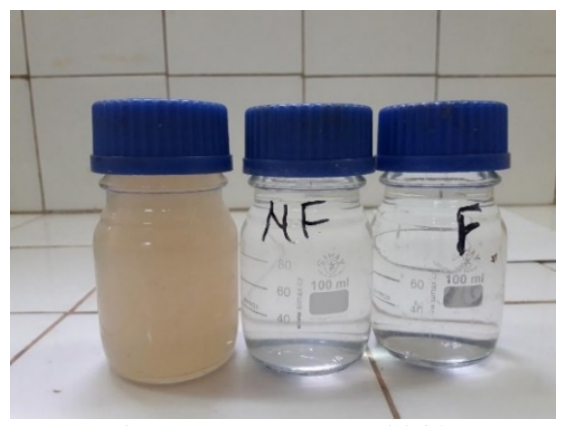

Source: Kaboré A. 2018

Figure 5: Raw water $\left(\mathrm{S}_{2}\right)$, after coagulation-flocculation $(\mathrm{NF})$ and filtration $(\mathrm{F})$

Efficiency of sand filtration on microbiological quality of water after coagulation flocculation: Figures 6,7 and 8 show the microbiological quality of

raw water treated by coagulation flocculation $\left(T_{1}\right)$ and filtration $\left(T_{2}\right)$.

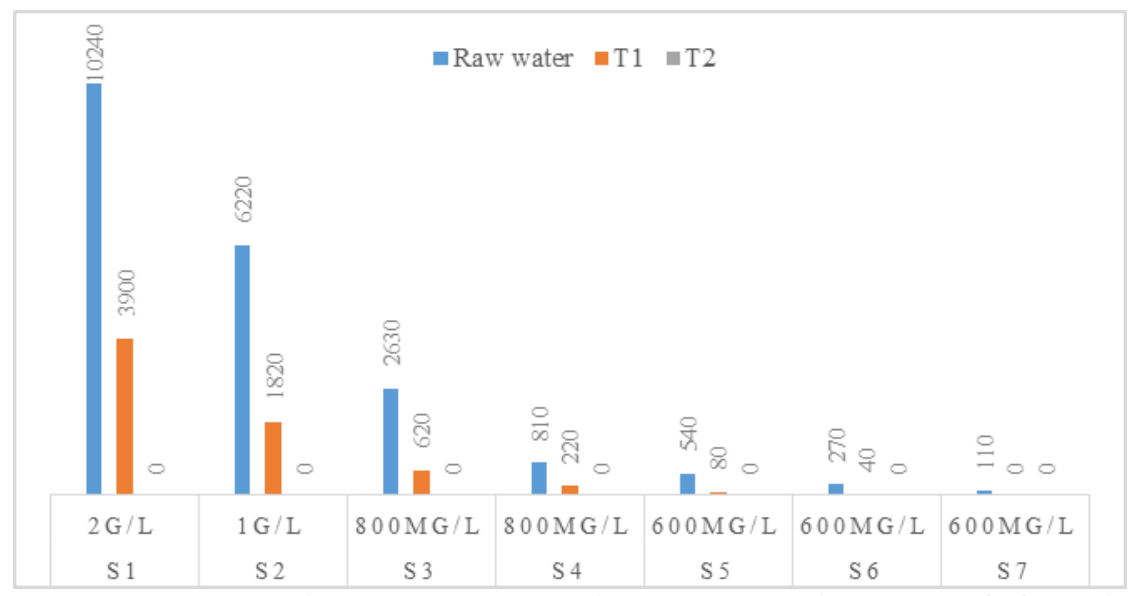

Figure 6: Faecal coliforms in raw water, after coagulation flocculation $\left(T_{1}\right)$ and filtration $\left(T_{2}\right)$

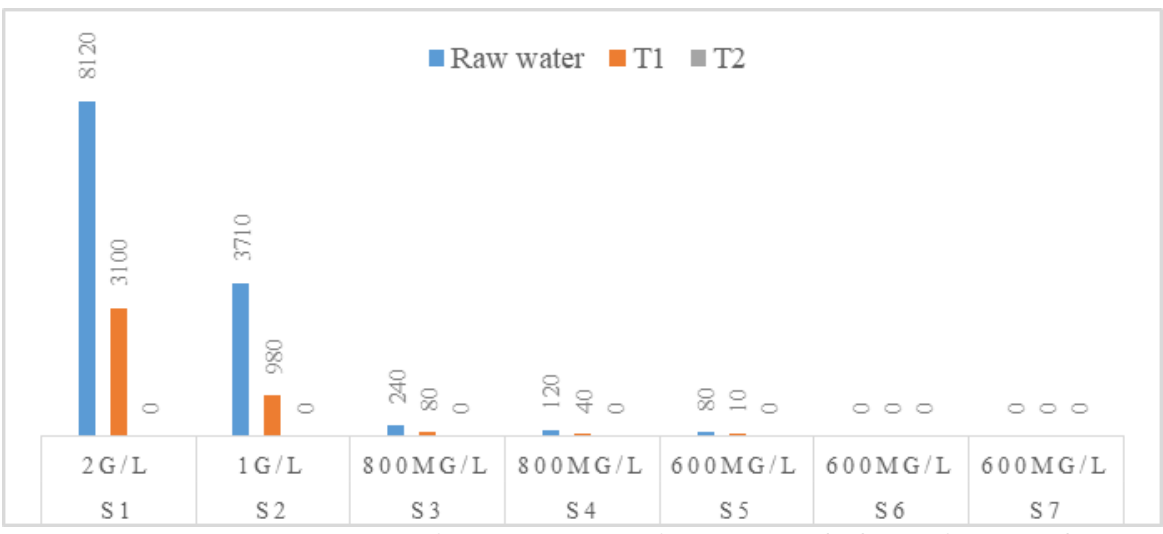

Figure 7: $E$. coli in raw water after coagulation flocculation $\left(T_{1}\right)$ and filtration $\left(T_{2}\right)$ 


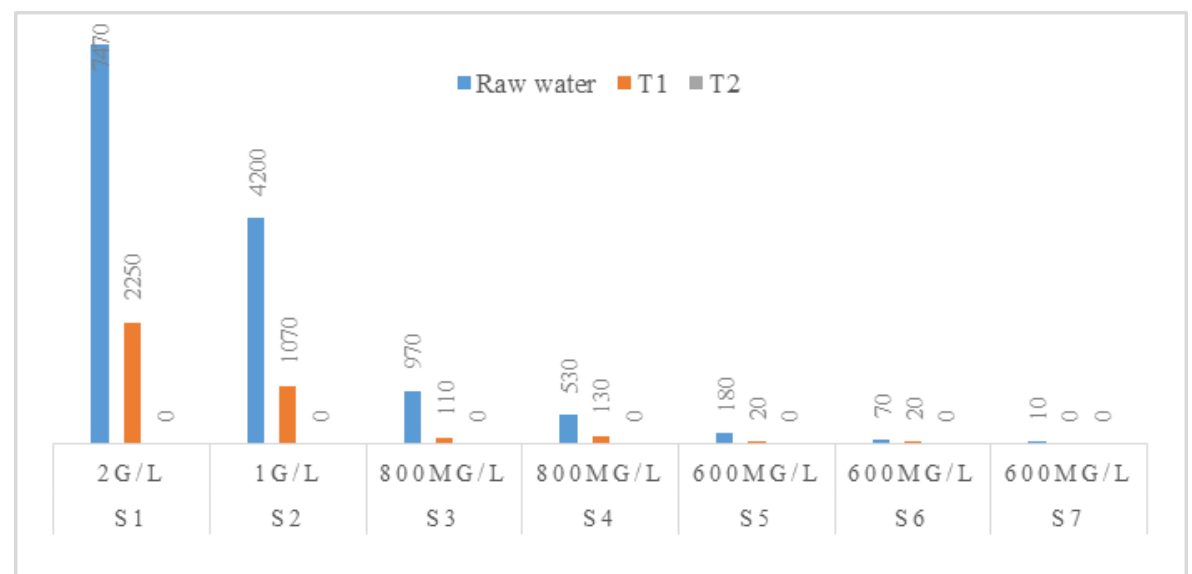

Figure 8: Faecal streptococci in raw water, after coagulation flocculation $\left(T_{1}\right)$ and filtration $\left(T_{2}\right)$

Depending on water type, 61.9 to $85.18 \%$ of faecal coliforms, 61.18 to $100 \%$ of $E$. coli and 69.88 to $100 \%$ of faecal streptococci were removed of water treated only by flocculation coagulation (figures $6,7,8$ ). If raw water does not contain many microorganisms, the coagulation flocculation only can removed all germs (Kaboré et al., 2013b). Otherwise, sand filtration is necessary to get drinking water. Combining sand filtration with coagulation flocculation removed all faecal bacteria in water. This related to the retention of microorganisms on sand. Therefore, coagulation

\section{CONCLUSION}

The sand filtration combined to coagulation flocculation of Moringa oleifera oilcake removed the residual organic matter induced by the coagulant and microorganisms in water. The water treated by this process is conform to WHO standards. In view of these flocculation with $M$. oleifera oilcake combined to sand filtration removed $100 \%$ of faecal bacteria in water, providing drinking water for consumption. Overall, the combination of sand filtration in coagulation flocculation of water with $M$. oleifera oilcake is an effective process to supply drinking water in household in rural area. Furthermore, the materials used as Moringa seeds, sand and shea charcoal are available and easy to get to rural population. The process is also fast and easy to implement in the house hold level.

results, a household treatment process adapted to the socio-economic conditions of rural populations should be formulated to popularise this technology of drinking water treatment.

\section{ACKNOWLEDGEMENTS}

The authors address their thanks to International Foundation for Science (IFS), which funded this study through a Research Grant (№ W/5405-2).

\section{BIBLIOGRAPHY}

Fatombi JK, Jossé RG, Wotto V., Aminou T., Coulomb B., 2007. Paramètres physico-chimiques de l'eau d'Opkara traitée par les graines de Moringa oleifera. Société Ouest Africaine De Chimie, vol. 23, 75-79.

Folkard G., Sutherland J., Al-Khalili R.S, 2002. La clarification de l'eau par coagulation en utilisant les graines du Moringa oleifera. In: L. Fuglie, L'arbre de la vie, les multiples usages du Moringa. CWS/CTA, Dakar, Sénégal, 7982.
Initiative Africaine Concertée sur la Réforme Budgétaire (CABRI), 2017. Accès à l'eau et à l'assainissement en milieu rural: un défi en matière de politiques au Burkina Faso, Africa Media Online $16 \mathrm{pp}$.

Institut National de la Statistique et de la Démographie, 2015. Résultats de l'Enquête Multisectorielle Continue 2014: Habitat, Assainissement et accès à l'eau potable, Burkina Faso, 49 pp.

Sawadogo J, 2019. Filtration de l'eau à base de matériaux locaux: cas des eaux de puits et de barrage du village de Péelé, commune rurale 
de Koubri au Burkina Faso, Mémoire de Master 2, Institut de Génie de l'Environnement et du Développement Durable, Université Ouaga 1, $41 \mathrm{pp}$.

Kaboré A, 2015. Optimisation des qualités épuratoires des graines de Moringa oleifera dans le traitement domestique des eaux de consommation en Afrique sub-saharienne: cas des eaux du Burkina Faso, Thèse de doctorat unique, Université de Ouagadougou, Burkina Faso, 197pp.

Kaboré A., Savadogo B., Otoidobiga HC, Sawadogo A., Rosillon F., Traoré AS, Dianou D, 2015. Microbiological quality of surface water treated with Moringa oleifera seeds or cakes during the storage: Case study of water reservoirs of Loumbila, Ziga and Ouaga 3 dams in Burkina Faso. Journal of Water Resource and Protection, Vol.7, 4, 312-321.

Kaboré A., Savadogo B., Rosillon F., Traoré AS, Dianou D, 2013a. Effectiveness of Moringa oleifera Defatted Cake versus Seed in the Treatment of Unsafe Drinking Water: Case Study of Surface and Well Waters in Burkina Faso. Journal of Water Resource and Protection, 5, 1076-1086.

Kaboré A., Savadogo B., Rosillon F., Traoré AS, Dianou D, 2013b. Optimisation de l'efficacité des graines de Moringa oleifera dans le traitement des eaux de Consommation en Afrique sub-saharienne: cas des eaux du Burkina Faso. Revue des Sciences de l'Eau 26(3), 209-220.

Norme Française NF EN ISO 8199, 2018. Exigences et lignes directrices générales pour les examens microbiologiques sur milieu de culture. Indice de classement: T 90-400, Novembre 2018.

Programme National d'Approvisionnement en Eau Potable à l'horizon 2030, 2018. Rapport bilan national au 31 décembre 2017, Ministère de l'Eau et de l'Assainissement, Burkina Faso, 58 $\mathrm{pp}$.

Rodier J., Legube B., Merletn N, 2009. The Water Analysis 9th Edition, Dunod Paris, 2009 ISBN 978-2-10-054179-9, 1579 pp.

Traoré I. and Sié A, 2017. Evaluation des effets du projet SANIEST sur les maladies relatives à l'eau, à l'hygiène et a l'assainissement dans six communes rurales du Burkina Faso, rapport d'étude. IRC-Burkina Faso, 37pp.
Savadogo B., Kaboré A, Zongo D., Poda JN., Bado H., Rosillon F., Dianou D., 2013. Problematic of drinking water access in rural area: case study of the Sourou valley in Burkina Faso. Journal of Environmental Protection, 4, 31-50.Van Minh $H_{\text {., }}$ Nguyen-Viet $H, 2011$. Economic aspects of sanitation in developing countries. Environ Health Insights. 5: 63-70. Vikashni N., Matakite M., Kanayathu K., Subramanium S., 2012. Water Purification using Moringa oleifera and Other Locally Available Seeds in Fiji for Heavy Metal Removal. International Journal of Applied Science and Technology, Vol. 2, 5, 125-129. WHO)/UNICE, 2018. Progress on drinking water, sanitation and hygiene: 2017 update and SDG baselines, ISBN 978-92-4251289-2, Geneva, 116p.https://creativecommons.org/licenses/bync-sa/3.0/igo WHO, 2011. Quality guidelines for drinking water. 4th Edition, WHO, ISBN 978 92 41548151, Geneva, Switzerland, 2011, 531 pp. World Health Organization, 2014. Preventing diarrhoea through better water, sanitation and hygiene, WHO Library Cataloging-in-Publication, ISBN 978924 156482 http://apps.who.int/iris/bitstream/10665/150112 11/9789241564823 